\title{
Strategies to Motivate Learners to Learn the Writing Skill: Case Study Students at the University of Bechar-Algeria
}

\author{
Fatiha Guessabi \\ Muhammed Tahri University of Bechar, Algeria
}

\begin{abstract}
Writing in a foreign language is one of the most challenging and complex tasks for learners. It is a difficult skill that requires considerable effort and practice on the student's part to reach an acceptable level of writing. Due to the complexity of this skill, many students find it very difficult to produce an adequate piece of writing. In this research, we aim to make our students aware about the fact that the development of the writing skill involves dealing with writing as a process that entails different stages and not as a product of accurate use of grammar and vocabulary. Students should be aware of the writing process through the intensive practice of writing which leads to the effective use of the writing techniques that allow them to decide about what to write, how to write, and how to evaluate what they write. Thus, making students aware of the different processes of writing will help them to overcome the difficulties they face when they write and to produce well written texts. It is by the means of two questionnaires addressed to both teachers and students from different secondary schools that we will investigate our hypothesis. The findings gathered in this study confirmed that the problems students face in writing can be avoided, and effective production can be achieved if they are aware of the importance of the writing process. Thus, this study is based on a brief theoretical literature overview, analysis of the activities in the language classroom and analysis of the results of the survey.
\end{abstract}

Keywords: Writing skill, learners, teachers, EFL Classroom, secondary school, activities in the language classroom.

\section{Introduction}

The long debate on foreign language pedagogy and language instructional practices has not yet improved its worth due to the disconnect teaching of foreign language skills. Learning a foreign language requires experience of learners on the foreign language skills: listening, speaking, reading and writing. The aim of dealing with different tasks is to acquire the ability of receiving and producing English language and to improve the pupil's abilities. Therefore the writing skill is regarded as the most difficult task among the four skills; it seems to be not an easy task for English language pupils who require a regular practice by using some strategies and motivation. Some researchers suggested applying some motivational strategies is beneficial to language development overall, but whether it is beneficial to develop all the skills of second language learning is not known, because certain skills may be developed in different manners. Obviously, writing is considered as the major skill to be developed for learning a second language. Pupils do not find it to be the most important to be motivated to write conscientiously towards a specific subject, or motivated to perform well for a serious audience. The educators need to give pupils writing motivation by framing assignments differently and giving pupils a "real" audience so that preparation can be made for their future writing as college pupils and professionals. The majority of our students do not perceive themselves as part of an educational community. Good teachers can relate any subject/material to pupils. Many pupils consider learning a chore that they do within the walls of the classroom. They write in the void of whatever a class may be studying and are not given the chance to realize that writing matters. Furthermore, the pupils are not motivated to write with the audience in mind because a single teacher is 
the audience for most assignments. Therefore, the problem we are confronted in this research is the existing of relationship between the teacher and pupils to develop the writing skill. The precise question is:

- Are the teachers able to develop their pupils' writing skill through using motivational strategies?

- Appling some motivational strategies while teaching writing skill is beneficial or not?

The present study aims at raising the awareness of the important role of the writing skill which is considered as an essential tool for learning and simply another way of communication. In addition this research aim at investigating how teachers applied some motivational strategies in order to enhance pupils writing level and figure out the reasons of the lack to of improving this skill. Thus, its main aim is to better understand how and to what extent are secondary school pupils motivated to learn the writing skill. Hence, applying different motivational strategies in the classroom in which pupils learn English gives a lot of opportunities for natural language use. It enables the pupils to interact and write freely. This leads us to hypothesize that: If the pupils are motivated through using strategies in order to write, their writing level would improve and develop.

\section{Methodology of the Research}

The populations of these samples are teachers and pupils at secondary schools in Bechar(south west of Algeria). Our study took a place in the secondary school, and the target population are samples from four different schools. We prefer to select secondary school pupils, because they will be aware of the strategies that are given by the teachers to learn the writing skill. The sample consists of 80 from both scientific and literary and foreign language streams, the overall age range of the pupils is from fifteen to twenty, for the academic year 2017/2018. Further, the samples consist of twelve English teachers of secondary school, from different ages ranged from 25 to 50 and teaching experience from two to fifteen years. Regarding qualifications, the majority licence /master held degrees in English education.

The data will be collected through teachers' interview and students' questionnaire. The teachers' interview aims at investigating the teachers' opinions about applying motivational strategies to enhance the pupils writing skill. The pupils' questionnaire aims to figure out the lack of this skill among pupils and whether they give importance and value to writing skill. The analysis of the collected data aims at determining the interactive elements that will provide the basis for the development of the writing skill. In order to conduct our research, answering the questions behind our investigation, and validating our hypotheses. The classroom observation is carried out under qualitative methods (appendix) to observe pupil's behaviour in the class directly and it stands to help our investigation by figuring out some practical aspects, techniques, and procedures adopted in the classroom. The classroom observation was done in secondary schools in Bechar.

\section{Data Analysis and Interpretations :}

\subsection{Part one: Data Analysis of the Teachers' Interview}

This part is devoted to get background information about the chosen sample of teachers. The first is about gender (Q2) is about the degree(s) held to see if the high degrees are needed or it is sufficient to be a great teacher with a first degree (B.A) to teach English language, without any consideration to the high degrees. Teachers are also asked how long have they been engaged in teaching English in secondary school in (Q3), because we need to know whether those teachers have already experienced in teaching or not. In the last question (Q4) we asked the teachers about the favorite skill they prefer to teach. 


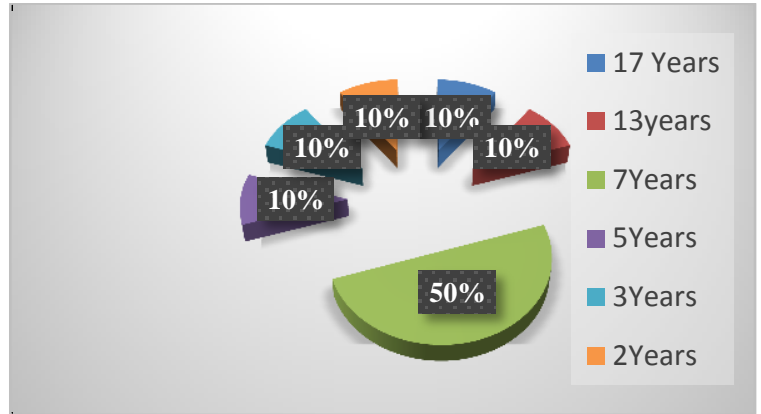

Fig. 1: Teacher experience in teaching

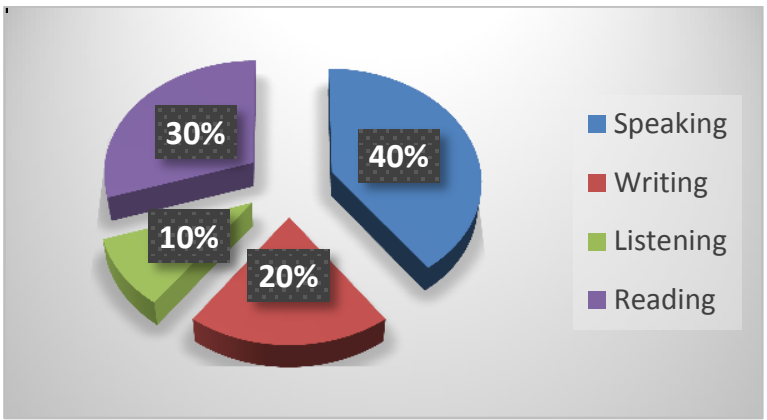

Fig. 2: The Favorite skill that teachers prefer to teach.

The figure one shows the results of how much time teacher spend their time in their teaching experiences most of them $50 \%$ spent 7 years in teaching $10 \%$ spent 17 Years, $10 \%$ spent 13 years, while $10 \%$ spent two years. Concerning the four skills most of the teachers (40\%) have chosen speaking. (30\%) select reading whereas $20 \%$ of teachers chose writing and only (10\%) for listening skill.

\subsection{Part Two: The second part of teachers' questionnaire is made in order to know how effectively to teach English writing skill.}

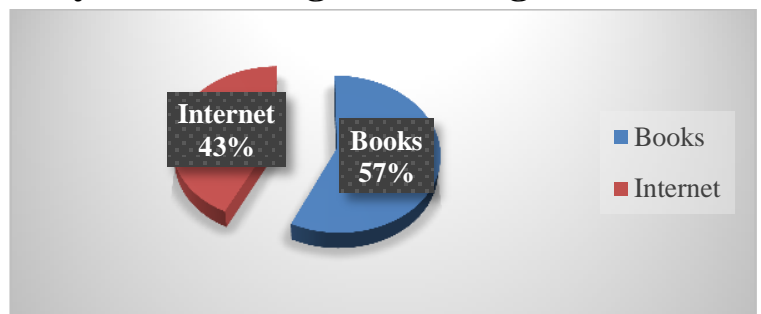

Fig. 3: Opinion of Teachers Concerning the Textbook

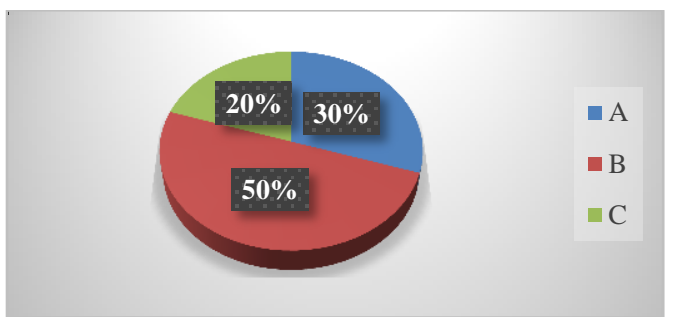

Fig. 4: Learners' Language Needs.

According to the chart $\mathrm{n}^{\circ} 3$, it is clearly noticed that the majority of the teachers $(70 \%)$ consider the text book as effective reliable and motivation sources, while (30\%) are not. The chart $\mathrm{n}^{\circ} 4$ illustrates that ( 50\%) of teachers declare that their pupils need clarity and simplicity they need to engage more in writing activities, $(30 \%)$ they use visual aids, while (20\%) motivate them with writing activities.

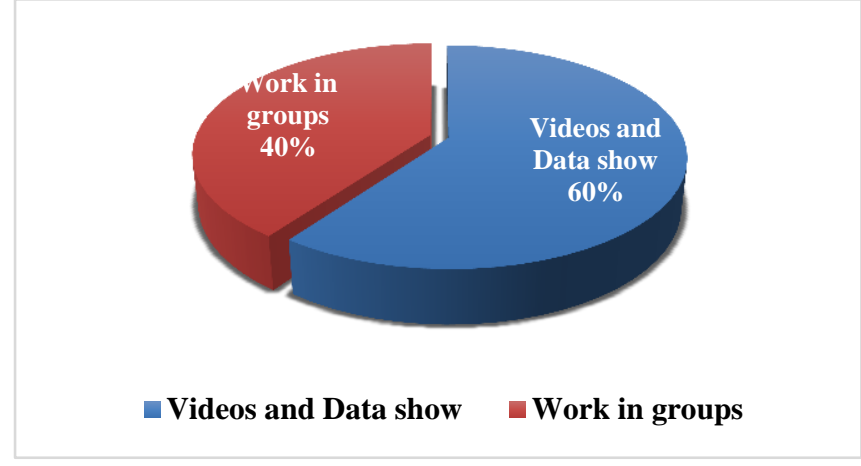

Fig. 5: Teacher's way to motivate their pupils

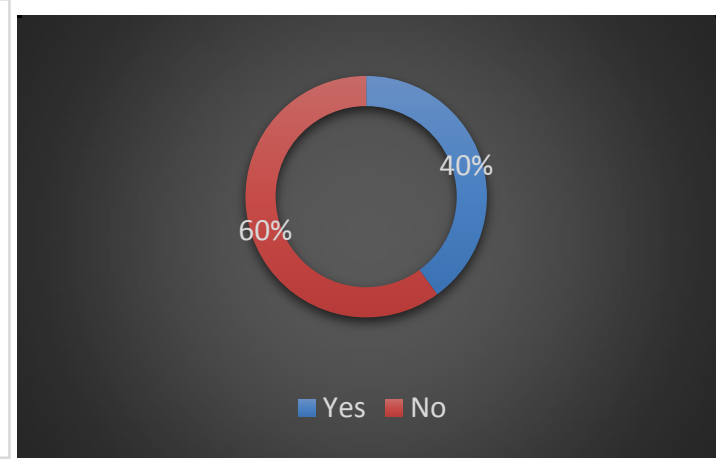

Fig. 6: pupil's level in writing in English

In figure 5 it is noticed that the majority $(60 \%)$ use data show and videos and their pupils like it, whereas (40\%) they said that their pupils like to work in groups. Teachers are asked to evaluate their pupils level in writing (fig.6) (60\%) of teachers stated that they are not satisfied with their pupils writing because they need more efforts and more vocabulary and grammar and only (40\%) affirmed that they are satisfied. 

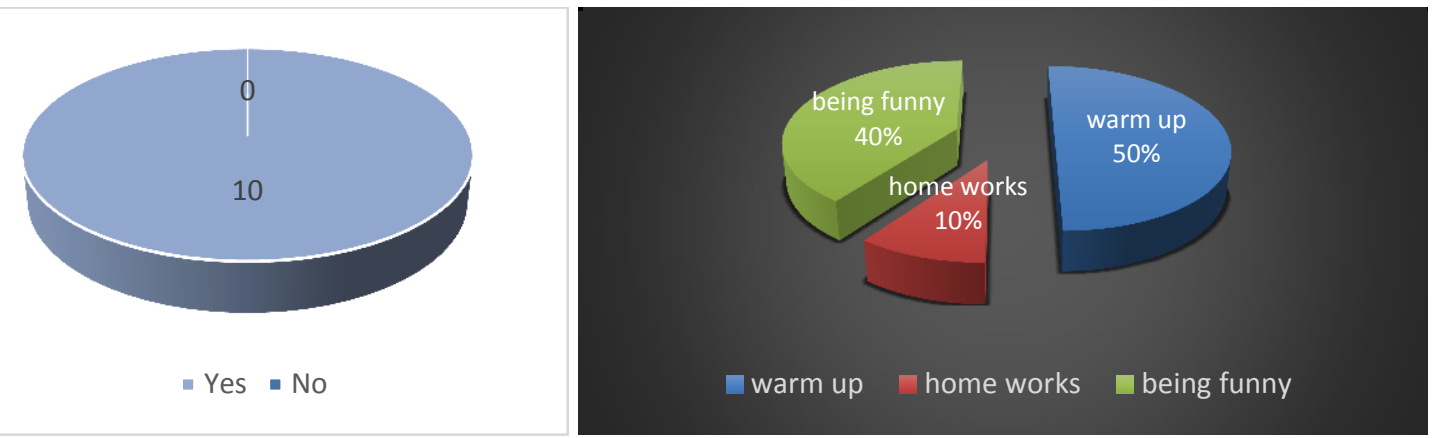

Fig. 7: Teachers guide their pupils when they write

Fig.8: Teachers method to motivate their pupils

It is noticed in fig.7 that all the percentage $(100 \%)$ of the teachers stated that they guide their pupils when they wrote paragraphs and sentences using planning and organization. In fig. $8(50 \%)$ of teachers motivate their pupils; they warm them up at the beginning of the session, whereas (40\%) declared that being funny dealing with topics they can interest them. And only (10\%) said that they motivate their pupils with home works and projects.

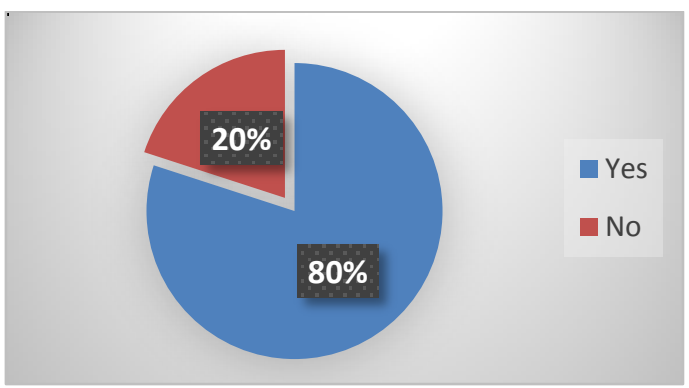

Fig. 9: English writing difficulties gap fillings, dictation,reordering paragraphs and note taking

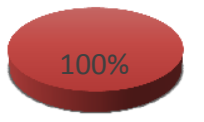

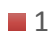

Fig. 10: Teacher's focuses in classroom

In the chart 9 ( $20 \%$ ) responded positively, while the majority (80\% ) say that their pupils face a big problems in their writing due to their low level in foreign language .According to teachers in fig. 10 (100\%) of dictation, reordering paragraphs, gap fillings and note taking are important to develop a good piece of writing.

\subsection{Part three: Data Analysis of the Pupils' Questionnaire:}

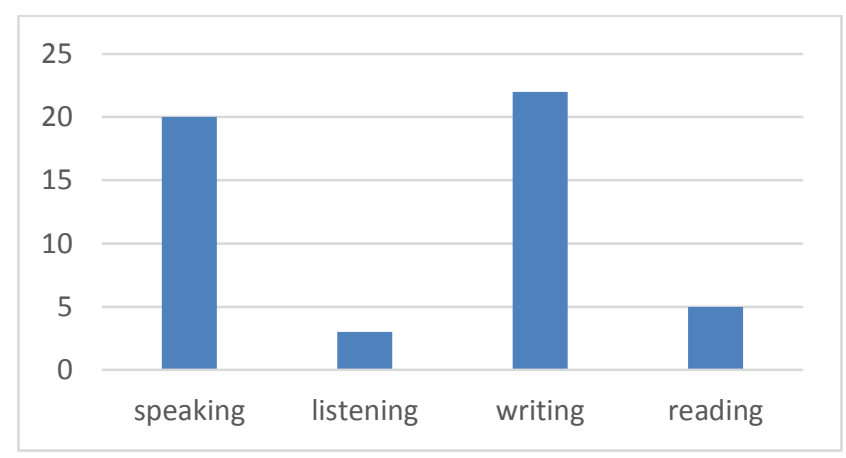

Fig. 11: The most desired language skills to be mastered

Among the four skills, writing skill is the preferable since (44\%) want to master most than the other ones. Speaking is the second chosen skill (40\%), (10\%) like writing and only $(6 \%)$ choose reading. 

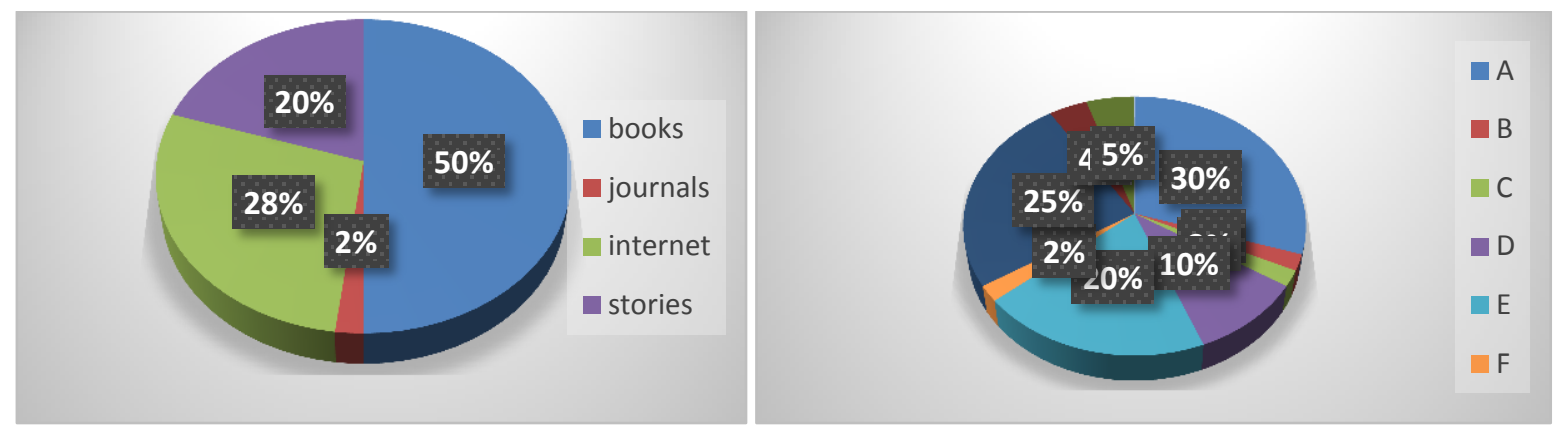

Fig. 12: Materials used by the teacher to help in learning writing

Fig. 13: The most useful activities to write

The fig. 12 shows $50 \%$ from the learners say the teachers use books to help them to learn the writing skill, $2 \%$ select journal, $28 \%$ select internet and $20 \%$ for stories. The fig. 13 is about the most useful and enjoyable activities, $30 \%$ select writing consequences, $2 \%$ select poems for the future, $2 \%$ select writing through reverse reading, $10 \%$ Role play writing, $20 \%$ creating a framework for writing, $2 \%$ a perfect story, $25 \%$ note writing, $4 \%$ eliciting vocabulary before writing narrative and 5\% improving paragraph writing.

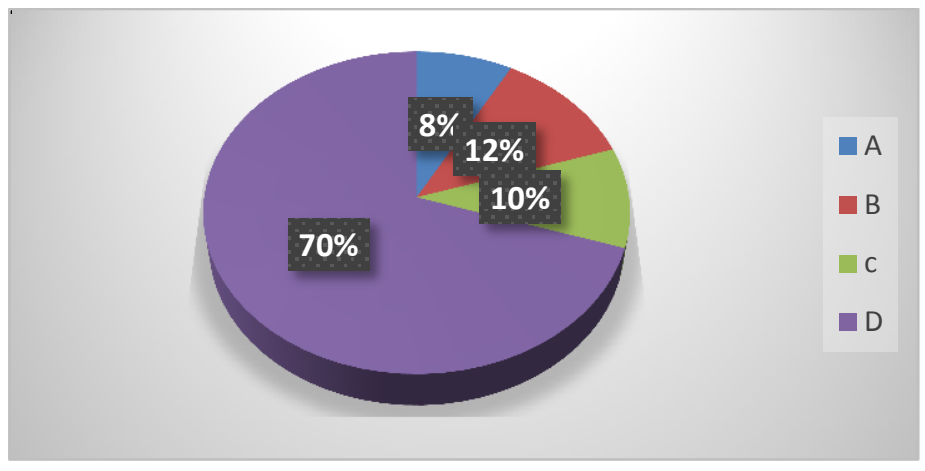

Fig. 14: Strategies that help pupils' learn better

In fig. 14, it is shown that the majority selected practice and play with revision techniques which is $70 \%$ and 8\% made dialogue on Face book between students from different schools who are reading the same book, 12\% work with words relevant to students lives to help them build vocabularies and $10 \%$ the teachers gave them chance to write to an audience for real purpose.

\section{Results and Discussions :}

Pupils do not want to write because they feel fear of making mistakes in front of their teachers and classmates in addition the low of motivation and joyful atmosphere during the class session make pupils not interesting for a successful learning skills i.e. they are less motivated to learn this task; however, according to the pupils questionnaire result are rather motivated to write, they just need some support. While the results of teachers' interview reflect another reality as the teachers complain about pupils' low motivation towards writing.

\subsection{Teachers' Interview}

The goal behind designing the teachers' interview was to raise some professional identification of the questions under the study. In addition, putting stress on the role and the importance of the pupils language proficiency in sessions of writing skills, as being the guide tool to transmit information, and by which they communicate in the English language.

Part one: The first background information of the teacher's interview, the responses reveal that the chosen samples contain more females $(70 \%)$ than males $(30 \%)$. The first fact deals with the natural appearance of the 
female side in the pedagogical area, i.e. women are motivated to work in the field of teaching whereas men are not. Concerning Q2 most who responded to our interview have BA license (50\%) or MA master (50\%) and unfortunately no one has a PHD. In (Q3) two teachers have a long teaching experience, since they have spent from 13 to 17 years in teaching English, whereas five teachers spent 7years and the rest of teachers from 2 to 5years. The result of $(\mathrm{Q} 4)$ is about the favorite skill that the teacher prefer to teach in order to know the useful and important for good English language, most of the teachers (40\%) have chosen speaking. (30\%) select reading whereas $20 \%$ of teachers chose writing and only (10\%) for listening skill. Part two: this part of the work gives a weighty function to this research. In teaching writing skill, this question (Q5) stressed to know if the teachers regard the text book as motivation tool for his pupils. The majority answer positively (57\%) and (43\%) answer negatively. In (Q6) was set to know the most motivational needs that are used by the teachers, and the answers of this question were not interesting and out. The seventh question stressed to figure out the useful material used by the teacher to assist the pupils to write, (40\%) of teachers used books because it useful and helpful to learn better, (30\%) declared that they use internet, (20\%) for stories whereas (10\%) for journals, the last question in part two (Q8) is about the most motivational strategies that are applied by the teacher in the classroom, we noticed that the majority $(60 \%)$ say that they use data show and videos because their pupils like it and enjoy it, whereas (40\%) say that their pupils like to work in groups. Part three: the quality of classroom interaction. The results estimate the truth about the importance given to the classroom interaction, the (Q9) set to know the level of pupils writing $(60 \%)$ of the teachers are not satisfied because their pupils need more efforts, vocabulary and grammar and only(40\%) affirmed that they are satisfied. (Q10) we asked the teachers if he guide his pupils through using strategies and methods when they write, all the percentage (100\%) reveal that they guide them when they wrote paragraphs and sentences using planning and organization. (Q11) set to know the teachers duty to motivate their pupils to write $(50 \%)$ of teachers motivate their pupils; they warm them up at the beginning of the session, whereas (40\%) declared that being funny dealing with topics they can interest them. And only (10\%) said that they motivate their pupils with home works and projects. This question (Q12) stressed to know if pupils face difficulties when they write or not the majority (80\%) respond negatively and the reason behind that due to their low level in English language, and the rest(20\%) respond positively.(Q13) aim at figure out the most comfortable skill may help the pupils to express their ideas, The majority of teachers (60\%) focus on speaking whereas only (30\%) focus on writing and (10\%) for reading and no one select listening skill. The last question(Q14) in this section is about the most useful writing activities that the teacher focus more in the classroom to develop a good piece of writing, for (100\%) of teachers select dictation, reordering paragraphs, gap fillings and note taking are important to develop a good piece of writing. Thus the obtained results show that writing skill is a complex activity that requires much time and practice from the learner's part and a lot of experience and guiding from the teacher's part. Teachers should guide pupils through the writing.

\subsection{Pupils Questionnaire:}

This questionnaire consists of twelve (12) questions which are arranged in a logical way. They are either closed questions requiring from the pupils to choose yes or no answers, or to pick up the appropriate answer from number of choices or open question requiring from them to give their own answers and justify them. Questions (1) to (4) are devoted to pupils' background information. (Q1) is about pupil's profil age, their age ranged from 17 to 19 years old (56\%) are 17 years old, (36\%) are 18 years old, and (8\%) are 19. (Q2) is to specify their gender, we have recorded only 14 males out of a total 50; making up (44\%) whereas the rest is of females, making up 28, (56\%). In the third question we asked about the most desired skill that the pupils wish to be mastered among the four skills, writing skill is the preferable since (44\%) want to master most than the other ones. Speaking is the second chosen skill (40\%), (10\%) like writing and only (6\%) choose reading. In (Q4) pupils are asked if they are satisfied with their writing, (48\%) of them stated that they are satisfied with their writing while $(52 \%)$ are not. This particular part of the research contributes in a large sense in the growth of the pupils need to develop a shortcut to the writing skill. (Q5) the majority (50\%)stated that the teacher use books to 
help them to learn, $(28 \%)$ say that their teacher use internet (20\%) for stories and only(2\%) select journals. The sixth question it is about the most activities that the teacher use it and their pupils like it , 30\% select writing consequences, $2 \%$ select poems for the future, $2 \%$ select writing through reverse reading, $10 \%$ Role play writing, $20 \%$ creating a framework for writing, $2 \%$ a perfect story, $25 \%$ note writing, $4 \%$ eliciting vocabulary before writing narrative and 5\% improving paragraph writing. The majority in (Q7) select Practice and play with revision techniques which is $70 \%$ and $8 \%$ use Establish an Face book dialogue between students from different schools who are reading the same book, $12 \%$ Work with words relevant to students lives to help you build vocabulary and $10 \%$ Gives you chance to write to an audience for real purpose.

\subsection{Classroom Interaction}

Classroom interaction is the last concern in this questionnaire, Teacher-pupils interaction could be more successful if the pupils feel at ease with their teachers and this may be due to the personality of both of them, in (Q8) we take pupils Opinion toward Teacher motivation in writing skill, according to the result the high percentage 52\% say (No) and $48 \%$ say (Yes), the ninth question is about the comfort skill that make pupils express their idea a high percentage, $72 \%$ select speaking and $28 \%$ select writing, the answers given in this question (Q10) show that while 2(4\%) pupils got a bad writing ability in the English language, 13 (26\%)respondents had a very well level at it.15(30\%) pupils admit that they have a well writing ability and the remaining 20(40\%)evaluated their level as being not so well. In question 11 (92\%) out of 100\% claimed that their teacher guide them to write through using planning organizing because they do not know the strategies of writing yet, However just (8\%) declared that do not guide them.(Q12)Pedagogically, a learning class atmosphere should be friendly, (62\%) of the participants revealed that the atmosphere of their class is friendly. We assume that they declared so because of the relationship that exists between them, however (30\%) declared that is boring. I believe that they do not participate and discuss which make them feeling so, and the rest (8\%) say that is stimulating.

Finally, the analysis of pupils' questionnaire reveals that pupils have a little difficulty in approaching the writing task. It confirm that writing is a challenging and complex skill, because pupils showed that they have difficulties in dealing with different aspects like grammar, vocabulary, content and ideas organization as well as the other mechanics of writing, spelling and punctuation. Furthermore, the results show that pupils have a little awareness about the writing process, but they lack the necessary awareness about the importance of going through all the writing stages for producing better composition.

\section{Conclusion}

It is detrimental to learn writing skill since the written expression is the life blood in any language learning. Learners tend to develop their writing, experiences or what every things that may affect the writer emotions and inspire them with an interesting subject. Hence, learning a foreign language, such as English, pupils acquire different skills and strategies within the classroom, and teachers integrate new learning styles, motivate pupils to write through using strategies and methods. It is by the means of two questionnaires devised to both teachers and pupils, the findings gathered in this study confirm that writing is a challenging skill and an activity that most of the pupils find difficulties when dealing with. Moreover, the results of the questionnaire approve our hypothesis that awareness about the writing process will lead to better compositions and prove that learners lack the necessary awareness about the recursive nature of writing and the importance of proceeding through the different writing stages for more effective writing. This study attempts to provide the Algerian teachers and pupils with an understanding of an effective way that leads to improve writing. Teachers should always urge their pupils to follow the writing process through the different stages. Pupils should know that the progressive activities are not a waste of time but rather a valuable practice that leads to the improvement of their level in writing.

According to the results, we recommend the following: first, the process stages should be taught explicitly and teachers should explain to pupils how every individual stage contributes in improving the writing outcome. 
Second, the process instructions should be introduced gradually but firmly. Before getting learners to write, teachers should encourage them to think about what they are going to write by planning the content and the sequence of what they will put down on paper. Second, teachers should encourage students to draft and reflect especially the ones who are unused to the writing process. Teachers should get learners to treat first drafts at first attempts and not as finished products. Finally, one way to involve learners in writing is to provide them with revision to use when looking through what they have written with an intention to make the appropriate modifications. Finally, teachers are the leading force in their classes, and pupils have the right to guide this power depending on their aptitude and attitude toward the target language. More precisely, students should develop their ability in writing skill, and we hope that these recommendations and other researchers' recommendations ameliorate the level of our learners; in this case, we wish our learners become good writers.

\section{References}

[1] Brown, H.D., Principles of Language Learning and Teaching, 4th ed., New York: Pearson Education, 2000.

[2] Csizer K. and Dornyei, Z. (2005), 'The Internal Structure of Language Learning Motivation and Its Relationship with Language Choice and Learning Effort'. The Modern Language Journal ,vol.89, nº 1pp. 19 - 36.

[3] Deci, E. L., \& Ryan, R. M., "Intrinsic motivation and self-determination in human behavior", New York: Plenum. Journal of International Education Research - Third Quarter, Volume 9, Number 3, 2013.

[4] Dev, P.C. (1997). 'Intrinsic motivation and academic achievement: What does their relationship imply for the classroom teacher?', Remedial and Special Education vol.18, ${ }^{\circ}{ }^{\circ}$ : pp12-19.

[5] Dörnyei Z, 'Motivation and Motivating in the Foreign Language Classroom.', The Modern Language Journal, The Modern Language Journal, Vol. 78, No. 3 (Autumn, 1994), pp. 273-284. Published by: Blackwell Publishing on behalf of the National Federation of Modern Language Teachers Associations.

[6] Dörnyei Zoltán,The Psychology of the Language Learner: Individual Differences in Second Language Acquisition(Second Language Acquisition Research Series), 1st Edition, Lawrence Erlbaum Associates Inc.,Publishers, 2005.

[7] Dornyei, Z. Attitudes, Orientations, and Motivations in Language Learning: Advances in Theory, Research and Applications, Oxford: Blackwell, 2003,pp 15-31.

[8] Gardner, R. and Lambert, W. (1959) 'Motivation al Variables in Second-Language Acquisition', Canadian Journal of Psychology, vol.13,nº,pp $266-272$.

[9] Gardner, R. and W. Lambert, Attitudes and Motivation in Second-Language Learning. Rowley, Ma: Newbury House, 1972.

[10] Gardner, R., P. Smythe, R. Clement, and L. Gliksman (1976) 'Second-Language learning: a social psychological perspective'. Canadian Modern Language Review 32: 198-213.

[11]Ivanic, R.,Writing and identity: The discoursal construction of identity in academic writing, Amsterdam: John Benjamins, 1998,p181.

[12] Keller, J. M., Motivational design of instruction, In C. M. Reigelruth (Ed.) Instructional Design Theories and Models: An Overview of their Current Status, Hillsdale, NJ: Lawrence Erlbaum, 1983, pp383-434.

[13] Klein, M., English Language Teaching, New York: Mc Graw Hill Companies Inc. 1985.

[14] Meyers A., Gateways to Academic Writing: Effective Sentences Paragraph and Essay, 1st ed., Pearson Education ESL. New York: Longman. 2005.

[15] Scheidecker, D. and Freeman, W., Bringing out the best in students: how legendary teachers motivate kids, London: SAGE, 1999.

[16] Scrivener, J., Learning Teaching: a Guidebook for English Language. $2^{\text {nd }}$ ed.,Macmillan publishers limited,UK, 2005.

[17] Templeton, S., \& Morris, D. (in press), Spelling, In P.D. Pearson, M. Kamil, R. Barr, \& P. Johnston (Eds.), Handbook of reading research (Vol. 3). White Plains, NY: Longman. 